\title{
Review: The Ageing Pancreas
}

\author{
Dr James E. Brown
}

Address for correspondence: Aston Research Centre for Healthy Ageing \& School of Life and Health Sciences, Aston University, Birmingham, B4 7ET, UK

Email: j.e.p.brown@aston.ac.uk

Telephone: 01212045039

Fax: 01212043696

Abbreviations and Acronyms

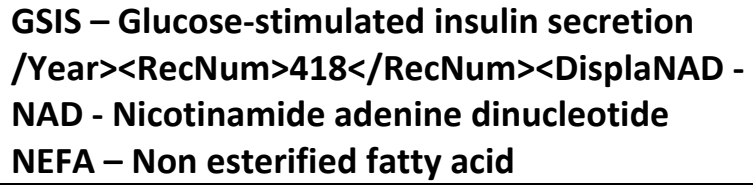

PDX-1 - Pancreatic and duodenal homeobox 1

SIRT1 - sirtuin 1

UCP2 - Uncoupling protein 2

\section{Abstract}

Type 2 diabetes is historically associated with older adults, and glucose tolerance is known to decline with advancing age. During the course of natural ageing, changes in many peripheral tissues contribute to this deterioration of glucose homeostasis. Included in this process are changes to the structure and function of the pancreatic islets, which undergo deviation in endocrine responses to glycaemic challenge. Current knowledge about the changes seen in the ageing pancreas is reviewed here.

\section{Introduction}

In the coming decades both developed and developing societies face a dual crisis of an increasingly ageing population and an increased prevalence of obesity and diabetes. It is commonly accepted that the UK population is becoming increasingly skewed towards older adults, (1), and alongside this, increases in obesity (1) and type 2 diabetes (2) represent significant health, social and economic pressures in the short to mid-term. This provides a unique challenge for scientists, physicians and policy makers.

The ageing process negatively affects the majority of tissues of the human body, including those associated with the onset of diabetes. It is now well established that the incidence of type 2 diabetes increases with age $(3,4)$ but specific reasons for this are as yet unclear. Diabetes significantly lowers the chances of successful aging, and notably increases functional limitations and impairs quality of life (5). Contemporary scientific opinion would suggest that this is most likely due to the gradual increase in insulin resistance seen in peripheral tissues as we age $(6,7)$. This phenomenon is therefore likely to increase due to the increasing prevalence of obesity and sedentary lifestyles (8, 9). Interestingly, however, key age-related changes in peripheral body composition, notably increased adiposity and decreased skeletal muscle mass, that are associated with insulin resistance 
have been shown to be insufficient on their own to account for the changes in glucose tolerance associated with type 2 diabetes (10).

One factor often overlooked when considering the close association between ageing and type 2 diabetes prevalence is the pancreas, and its ability to consistently maintain an appropriate endocrine output .

\section{Pancreatic islets and ageing: insulin secretion}

A primary role of the pancreatic islet is to synthesise, store and release insulin from the $\beta$-cells when required (11). $\beta$-cells make up approximately $55 \%$ of the cellular mass of a pancreatic islet (around $75 \%$ in rodents) and $\alpha$-cells $35 \%$ (17\% in rodents) (12). Figure 1 demonstrates diagrammatically the makeup of a human pancreatic islet. To successfully manage blood glucose levels, both pancreatic $\beta$-cell function and mass must be maintained, and both of these factors are known to be influenced by the ageing process.

The first of these essential factors influenced by age, insulin secretion, has been the focus of a significant amount of research over the previous two decades. Although initial studies provided conflicting data (13) it is now accepted that after a long period of normal, or even elevated insulin levels (particularly in obese individuals) insulin secretion falls with advancing age $(14,15)$, and this is independent of insulin action in peripheral tissues (16) While increased demands for more insulin are incurred by insulin resistance, several studies suggest that age-related decreases in insulin secretion are not due solely to the increased glycaemic pressure placed on pancreatic islets in a progressively insulin resistant environment, but that independent age-related factors are somehow involved. These 'insulin resistance-independent factors' are thought to include loss of expression of pancreatic $\beta$-adrenergic receptors (17), which would impinge upon adrenergic stimulation of insulin secretion. A dysregulation of sirtuin activity by pancreatic $\beta$-cells has been reported $(18,19)$, which might lead to changes in UCP2 activity leading to suppressed insulin secretion. Reduced circulating levels of the insulin secretion regulating vitamin $D$ have also been associated with age-related changes in insulin secretion (20) as well as dysregulated expression of the orphan GPR39 receptor (21). Further research has suggested that altered incretin levels (22) and NAD biosynthesis (23) might play a role in both secretion and biosynthesis of insulin in older animals (see Table 1). The incretin GIP appears to produce a $48 \%$ lower insulin secretion response with age (24) suggesting that incretin sensitivity may be impaired in older adults.

The reduction in insulin secretion seen in ageing has also been suggested to be due to decreased biosynthesis (25) and reduced stimulus-recognition-secretion-coupling $(26,27)$. As the islet releases many other molecules in addition to insulin, some of which can regulate insulin release, the possibility exists that changes in these molecules might be involved in age-related decline in insulin secretion. An example of this would be IAPP, which is co-secreted with insulin and which can aggregate within pancreatic islets and impair insulin release (28) 


\begin{tabular}{|c|c|c|c|}
\hline Factor & Role & Effect in ageing pancreas & Reference \\
\hline $\begin{array}{l}\text { Chromosomal } \\
\text { Telomere }\end{array}$ & $\begin{array}{c}\text { Protective } \\
\text { chromosomal } \\
\text { structure }\end{array}$ & $\begin{array}{l}\text { Decreased insulin secretion, } \\
\text { increased senescence }\end{array}$ & 59 \\
\hline GPR39 & Unknown & Decreased insulin secretion & 20 \\
\hline IAPP & $\begin{array}{l}\text { Slows gastric } \\
\text { emptying }\end{array}$ & Increased $\beta$-cell apoptosis & 28 \\
\hline Incretins (GLP-1, GIP) & $\begin{array}{l}\text { Modulators of post- } \\
\text { prandial islet response }\end{array}$ & $\begin{array}{l}\text { Decreased insulin secretion and } \\
\beta \text {-cell mass }\end{array}$ & 24 \\
\hline Incretins (GLP-1, GIP) & $\begin{array}{l}\text { Modulators of post- } \\
\text { prandial islet response }\end{array}$ & $\begin{array}{l}\text { Decreased insulin secretion and } \\
\beta \text {-cell mass }\end{array}$ & 24 \\
\hline NAD & Metabolic coenzyme & Decreased insulin secretion & 23 \\
\hline p16 ${ }^{\text {INK4a }}$ & Cell cycle regulator & Limited $\beta$-cell regeneration & 47 \\
\hline P2 receptor & $\begin{array}{l}\text { Cell surface nucleotide } \\
\text { receptor }\end{array}$ & Decreased insulin secretion & 48 \\
\hline PDX-1 & Transcription factor & $\begin{array}{l}\text { Decreased insulin transcription, } \\
\text { increased } \beta \text {-cell apoptosis }\end{array}$ & 45,50 \\
\hline Sirt1 & $\begin{array}{l}\text { Epigenetic gene } \\
\text { regulator }\end{array}$ & $\begin{array}{l}\text { Represses UCP2 leading to } \\
\text { decreased insulin secretion }\end{array}$ & 18,19 \\
\hline Vitamin D & Fat soluble vitamin & $\begin{array}{l}\text { Decreased insulin secretion and } \\
\text { sensitivity }\end{array}$ & 20 \\
\hline
\end{tabular}

Table 1. Factors associated with age-related decline in pancreatic function. Changes in the expression levels and activities of the molecules listed in this table have been associated with alterations in pancreatic islet function seen in older organisms.

Whatever the mechanism, it is clear that pancreatic $\beta$-cell function appears to decrease as glucose levels increase, even within the normal range (29) and that the insulin secretory capacity of the pancreas decreases with age (30-32). It has been suggested that insulin secretion decreases by $0.5 \%$ per year of life $(33,34)$ and that in people with type 2 diabetes a significant decrease occurs in the first few years post-diagnosis (35). Therefore, ageing has a significant effect on the first of our essential pancreatic factors, insulin secretion. Compounding this effect is the observation that increased hepatic clearance of insulin occurs, dampening the delivery of insulin to peripheral tissues (36). 


\section{Pancreatic islets and ageing: pancreatic $\beta$-cell mass}

Alongside pancreatic $\beta$-cell function, maintenance of effective pancreatic $\beta$-cell mass is essential in enabling the body to control blood glucose levels. Changes in the pancreatic islet seen in ageing are likely to be due to loss of $\beta$-cell mass, with little evidence of changes in the numbers or topographical location of other cell types, apart from in those who have diabetes where an expansion of $\alpha$-cells is seen (37). $\beta$-cell mass is under normal circumstances maintained by a relatively labile combination of $\beta$-cell neogenesis and apoptosis (38). A significant divergence in the levels of either of these two factors may therefore lead to a decrease in the total number of pancreatic $\beta$-cells, and a subsequent inability of the pancreas to respond to elevated blood glucose with an appropriate insulin secretory response. Much recent research has focussed upon the role of incretins (and their analogues) in the maintenance of $\beta$-cell mass, as a wealth of evidence of their role in this area (39-41) has led to the notion of incretin-based therapies being used not only to manage blood glucose levels, but also to support pancreatic $\beta$-cell mass (42). Additionally, research has suggested that cell-cell interactions within the islet are essential for insulin production, with connexins playing an important role (43).
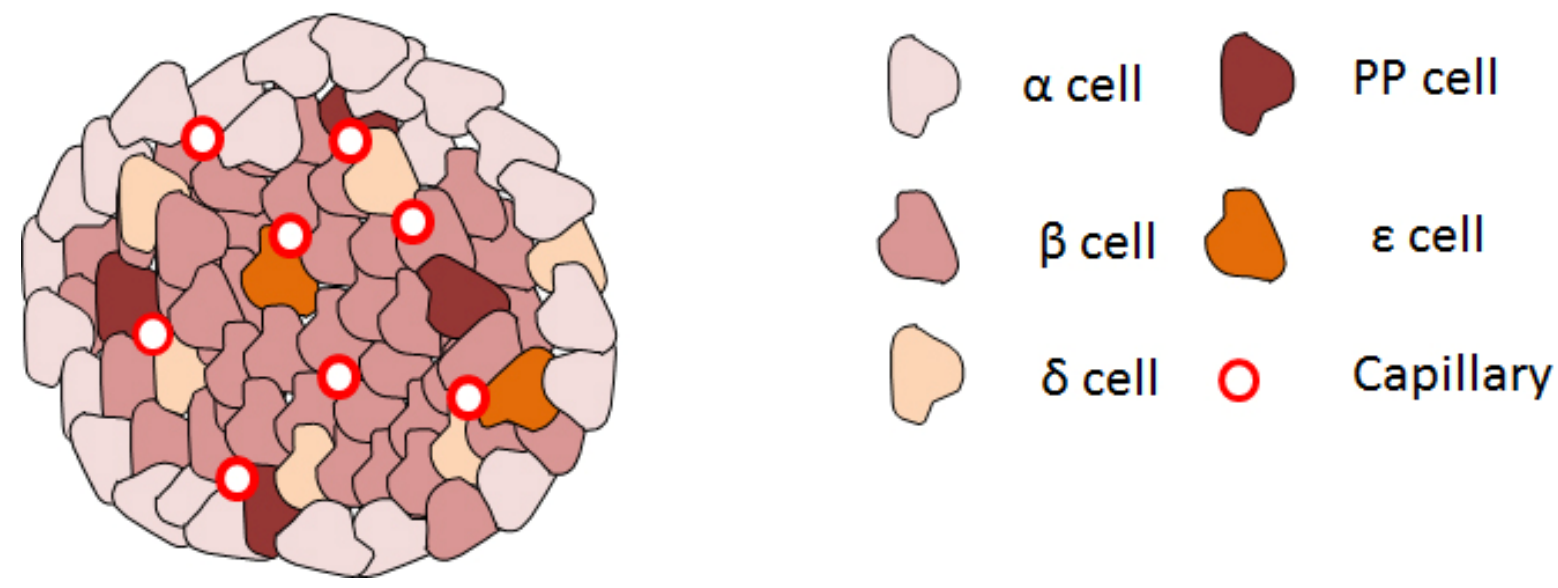

Figure 1. Diagrammatic representation of a pancreatic islet. Changes observed in pancreatic islets as they undergo ageing are thought to be due to a decreased number of $\beta$-cells with little evidence of changes seen in other cell types.

There is strong evidence in both rodents and humans that the ageing process leads to a reduced capacity for $\beta$-cell neogenesis or proliferation $(44,45)$. Equally, research has identified an age-related increase in sensitivity to apoptosis (45) in pancreatic $\beta$-cells and increased age-related $\beta$-cell apoptosis in the presence of obesity (46). As the level of cellular turnover in pancreatic islets is relatively slow, and appears to be limited to the first three decades of life (47), the ability of the pancreas to respond to apoptotic pressures exerted on it is significantly impaired .The mechanisms for increased apoptosis in ageing $\beta$-cells are thought to include accumulation of the tumour suppressor $\mathrm{p} 16^{\mathrm{INK} 4 \mathrm{a}}(48)$ and $\mathrm{P} 2$ receptor expression (49). In addition, it has been postulated that age-related changes in $\beta$-cell turnover (a result of both neogenesis and apoptosis) are due to 
reduced expression of the transcription factor PDX-1 $(45,50)$, an essential element in not only the transcription of insulin, but also a potent inhibitor of $\beta$-cell apoptosis $(51,52)$.

\section{The role of diabetes in pancreatic ageing}

The endocrine pancreas of a subject with type 2 diabetes clearly has a more challenging environment in which to age than that of a lean, healthy individual. The chronically elevated levels of both glucose and non-esterified saturated fatty acids that are a common occurrence in type 2 diabetes are known to reduce GSIS after chronic exposure, a phenomenon termed glucolipotoxicity $(53,54)$. Alongside the decrease in GSIS, elevated glucose and NEFAs are known to induce $\beta$-cell apoptosis and therefore compound their effects on insulin secretion (55). Interestingly, recent research has suggested that glucolipotoxicity impairs $\beta$-cell function in an age-dependent manner (56), causing diminished GSIS, proinsulin biosynthesis, lower cellular insulin content and reduced expression of $\beta$-cell gene expression. Suggested mechanisms for this toxicity include increased reactive oxygen species and decreased mitochondrial function (57), phenomena that have been shown to accumulate as islets age (58).

In addition to these well documented challenges, it has been reported that individuals with type 2 diabetes have accelerated shortening of telomeres, the regions of DNA repeats found at the end of chromosomes (59), leads to compromised $\beta$-cell survival (60) suggesting that the process of ageing itself can have a significant impact on the regenerative capacity of the endocrine pancreas.

\section{Conclusion}

As the human body ages, and especially as glycaemic pressures increase due to obesity or insulin resistance, our pancreatic islets change in morphology and function. Not only does the number of pancreatic $\beta$-cells decrease as the balance of new cell growth and apoptosis shifts, but the transcriptome and proteome of the islet changes to contribute to a tissue that is no longer fully able to perform its primary function and contributes to the increased incidence of diabetes seen in elderly populations.

\section{Key messages}

Insulin secretion decreases $0.5 \%$ per year

$\beta$-cell neogenesis and proliferation decrease with age

Ageing impairs ability of islet cells to perform their primary functions 


\section{References}

1. Wang YC, McPherson K, Marsh T, Gortmaker SL et al. Health and economic burden of the projected obesity trends in the USA and the UK. Lancet. 2011;378:815-25.

2. Bagust A, Hopkinson PK, Maslove L, Currie CJ. The projected health care burden of Type 2 diabetes in the UK from 2000 to 2060. Diabetic Med. 2002;19 Suppl 4:1-5.

3. Cowie CC, Rust KF, Byrd-Holt DD, Eberhardt MS et al. Prevalence of diabetes and impaired fasting glucose in adults in the U.S. population: National Health And Nutrition Examination Survey 1999-2002. Diabetes Care. 2006;29:1263-8.

4. Rathmann W, Strassburger K, Heier M, Holle R, et al. Incidence of Type 2 diabetes in the elderly German population and the effect of clinical and lifestyle risk factors: KORA S4/F4 cohort study. Diabetic Med. 2009;26:1212-9.

5. Viljoen A, Sinclair AJ. Diabetes and Insulin Resistance in Older People. Med Clin N Am. 2011;95:615.

6. Rowe JW, Minaker KL, Pallotta JA, Flier JS. Characterization of the insulin resistance of aging. The Journal of clinical investigation. 1983;71:1581-7.

7. Pagano G, Cassader M, Diana A, Pisu E, et al. Insulin resistance in the aged: the role of the peripheral insulin receptors. Metabolism. 1981;30:46-9.

8. Coen PM, Dube JJ, Amati F, Stefanovic-Racic M, et al. Insulin resistance is associated with higher intramyocellular triglycerides in type I but not type II myocytes concomitant with higher ceramide content. Diabetes. 2010;59:80-8.

9. Ferrannini E, Vichi S, Beck-Nielsen H, Laakso M et al. Insulin action and age. European Group for the Study of Insulin Resistance (EGIR). Diabetes. 1996;45:947-53.

10. lozzo P, Chareonthaitawee P, Dutka D, Betteridge DJ, et al. Independent association of type 2 diabetes and coronary artery disease with myocardial insulin resistance. Diabetes. 2002;51:3020-4.

11. Haist RE. Functions of the islets of Langerhans. Canadian Medical Association Journal. 1971;105:956-7.

12. Cabrera O, Berman DM, Kenyon NS, Ricordi C, et al. The unique cytoarchitecture of human pancreatic islets has implications for islet cell function. PNAS. 2006;103:2334-9.

13. Adelman RC. Secretion of insulin during aging. Journal of the American Geriatrics Society. 1989;37(10):983-90.

14. Ruhe RC, Curry DL, Herrmann S, McDonald RB. Age and gender effects on insulin secretion and glucose sensitivity of the endocrine pancreas. Am J of Physiol. 1992;262:R671-6.

15. Ihm SH, Moon HJ, Kang JG, Park CY, et al. Effect of aging on insulin secretory function and expression of beta cell function-related genes of islets. Diabetes Res Clin Pract. 2007;77 Suppl 1:S150-4. 
16. Muzumdar R, Ma X, Atzmon G, Vuguin $P$ et al. Decrease in glucose-stimulated insulin secretion with aging is independent of insulin action. Diabetes. 2004;53:441-6.

17. Santulli G, Lombardi A, Sorriento D, Anastasio A, et al. Age-Related Impairment in Insulin Release: The Essential Role of beta2-Adrenergic Receptor. Diabetes. 2012;61:692-701.

18. Ramsey KM, Mills KF, Satoh A, Imai S. Age-associated loss of Sirt1-mediated enhancement of glucose-stimulated insulin secretion in beta cell-specific Sirt1-overexpressing (BESTO) mice. Aging cell. 2008;7:78-88.

19. Bordone L, Motta MC, Picard F, Robinson A, et al. Sirt1 regulates insulin secretion by repressing UCP2 in pancreatic beta cells. PLoS biology. 2006;4:e31..

20. Alvarez JA, Ashraf A. Role of vitamin $d$ in insulin secretion and insulin sensitivity for glucose homeostasis. Int J Endocrinol. 2010:351385.

21. Tremblay F, Richard AM, Will S, Syed J, et al. Disruption of G protein-coupled receptor 39 impairs insulin secretion in vivo. Endocrinology. 2009;150:2586-95.

22. Elahi D, Andersen DK, Muller DC, Tobin JD et al. The enteric enhancement of glucosestimulated insulin release. The role of GIP in aging, obesity, and non-insulin-dependent diabetes mellitus. Diabetes. 1984;33:950-7.

23. Imai S. The NAD World: a new systemic regulatory network for metabolism and aging--Sirt1, systemic NAD biosynthesis, and their importance. Cell Biochem Biophys. 2009;53:65-74.

24. Elahi D, Andersen DK, Muller DC, Tobin JD et al. The Enteric Enhancement of GlucoseStimulated Insulin Release - the Role of Gip in Aging, Obesity, and Non-Insulin-Dependent DiabetesMellitus. Diabetes. 1984;33:950-7.

25. Wang SY, Halban PA, Rowe JW. Effects of aging on insulin synthesis and secretion. Differential effects on preproinsulin messenger RNA levels, proinsulin biosynthesis, and secretion of newly made and preformed insulin in the rat. JCI. 1988;81:176-84.

26. Reaven E, Kostrna M, Ramachandran J, Azhar S. Structure and function changes in rat adrenal glands during aging. Am J Physiol. 1988;255:E903-11.

27. Bailey CJ, Flatt PR. Hormonal control of glucose homeostasis during development and ageing in mice. Metabolism. 1982;31:238-46.

28. Tokuyama T, Yagui K, Yamaguchi T, Huang $\mathrm{Cl}$, et al. Expression of human islet amyloid polypeptide/amylin impairs insulin secretion in mouse pancreatic beta cells. Metabolism. 1997;46:1044-51.

29. van Haeften TW, Pimenta W, Mitrakou A, Korytkowski M et al. Relative conributions of betacell function and tissue insulin sensitivity to fasting and postglucose-load glycemia. Metabolism. 2000;49:1318-25. 
30. Utzschneider KM, Carr DB, Hull RL, Kodama K et al. Impact of intra-abdominal fat and age on insulin sensitivity and beta-cell function. Diabetes. 2004;53:2867-72.

31. Chiu KC, Martinez DS, Chu A. Comparison of the relationship of age and beta cell function in three ethnic groups. Clin Endocrinol (Oxf). 2005;62:296-302.

32. Chiu KC, Lee NP, Cohan P, Chuang LM. Beta cell function declines with age in glucose tolerant Caucasians. Clin Endocrinol (Oxf). 2000;53:569-75.

33. Szoke E, Shrayyef MZ, Messing S, Woerle HJ et al. Effect of aging on glucose homeostasis: accelerated deterioration of beta-cell function in individuals with impaired glucose tolerance. Diabetes Care. 2008;31:539-43.

34. Iozzo $P$, Beck-Nielsen $H$, Laakso $M$, Smith $U$ et al. Independent influence of age on basal insulin secretion in nondiabetic humans. European Group for the Study of Insulin Resistance. J Clin Endocrinol Metab. 1999;84(3):863-8.

35. U.K. prospective diabetes study 16 . Overview of 6 years' therapy of type II diabetes: a progressive disease. U.K. Prospective Diabetes Study Group. Diabetes. 1995;44:1249-58.

36. Matveyenko AV, Veldhuis JD, Butler PC. Adaptations in pulsatile insulin secretion, hepatic insulin clearance, and beta-cell mass to age-related insulin resistance in rats. Am J Physiol Endo Metab. 2008;295:E832-41.

37. Yoon $\mathrm{KH}, \mathrm{Ko} \mathrm{SH}, \mathrm{Cho} \mathrm{JH}$, Lee $\mathrm{JM}$ et al. Selective beta-cell loss and beta-cell expansion in patients with type 2 diabetes mellitus in Korea. J Clin Endocr Metab. 2003;88(5):2300-8.

38. Bouwens L, Rooman I. Regulation of pancreatic beta-cell mass. Physiol Rev. 2005;85:125570.

39. Rolin B, Larsen MO, Gotfredsen CF, Deacon CF et al. The long-acting GLP-1 derivative NN2211 ameliorates glycemia and increases beta-cell mass in diabetic mice. Am J Physiol Endo Metab. 2002;283:E745-E52.

40. Widenmaier SB, Kim SJ, Yang GK, De Los Reyes T et al. A GIP Receptor Agonist Exhibits betaCell Anti-Apoptotic Actions in Rat Models of Diabetes Resulting in Improved beta-Cell Function and Glycemic Control. PloS one. 2010;5.

41. Xu G, Stoffers DA, Habener JF, Bonner-Weir S. Exendin-4 stimulates both beta-cell replication and neogenesis, resulting in increased beta-cell mass and improved glucose tolerance in diabetic rats. Diabetes. 1999;48:2270-6.

42. Salehi M, Aulinger BA, D'Alessio DA. Targeting beta-cell mass in type 2 diabetes: Promise and limitations of new drugs based on incretins. Endocr Rev. 2008;29:367-79.

43. Vozzi C, Ullrich S, Charollais A, Philippe J et al. Adequate Connexin-Mediated Coupling Is Required for Proper Insulin Production. J Cell Biol. 1995;131:1561-72.

44. Swenne I. Effects of aging on the regenerative capacity of the pancreatic B-cell of the rat. Diabetes. 1983;32:14-9. 
45. Maedler K, Schumann DM, Schulthess F, Oberholzer J et al. Aging correlates with decreased beta-cell proliferative capacity and enhanced sensitivity to apoptosis: a potential role for Fas and pancreatic duodenal homeobox-1. Diabetes. 2006;55:2455-62.

46. Shimabukuro M, Zhou YT, Levi M, Unger RH. Fatty acid-induced beta cell apoptosis: a link between obesity and diabetes. PNAS. 1998;95:2498-502.

47. Perl S, Kushner JA, Buchholz BA, Meeker AK et al. Significant Human beta-Cell Turnover Is Limited to the First Three Decades of Life as Determined by in Vivo Thymidine Analog Incorporation and Radiocarbon Dating. J Clin Endocr Metab. 2010;95:E234-E9.

48. Krishnamurthy J, Ramsey MR, Ligon KL, Torrice $\mathrm{C}$ et al. p16INK4a induces an age-dependent decline in islet regenerative potential. Nature. 2006;443:453-7.

49. Coutinho-Silva R, Parsons M, Robson T, Burnstock G. Changes in expression of P2 receptors in rat and mouse pancreas during development and ageing. Cell Tissue Res. 2001;306:373-83.

50. Reers C, Erbel S, Esposito I, Schmied B et al. Impaired islet turnover in human donor pancreata with aging. Eur J Endocrinol. 2009;160:185-91.

51. Johnson JD, Bernal-Mizrachi E, Alejandro EU, Han $Z$ et al. Insulin protects islets from apoptosis via Pdx1 and specific changes in the human islet proteome. PNAS. 2006;103:19575-80..

52. Fujimoto K, Polonsky KS. Pdx1 and other factors that regulate pancreatic beta-cell survival. Diabetes Obes Metab. 2009;11 Suppl 4:30-7.

53. Poitout V. Glucolipotoxicity of the pancreatic beta-cell: myth or reality? Biochem Soc Trans. 2008;36:901-4.

54. Poitout V, Amyot J, Semache M, Zarrouki B et al. Glucolipotoxicity of the pancreatic beta cell. Biochim Biophys Acta. 2010;1801:289-98.

55. Veret J, Coant N, Berdyshev EV, Skobeleva A et al. Ceramide synthase 4 and de novo production of ceramides with specific $\mathrm{N}$-acyl chain lengths are involved in glucolipotoxicity-induced apoptosis of INS-1 beta-cells. Biochemical J. 2011;438:177-89.

56. Fontes G, Zarrouki B, Hagman DK, Latour MG et al. Glucolipotoxicity age-dependently impairs beta cell function in rats despite a marked increase in beta cell mass. Diabetologia. 2010;53:2369-79.

57. Poitout V, Robertson RP. Glucolipotoxicity: Fuel excess and beta-cell dysfunction. Endocr Rev. 2008;29:351-66.

58. Simmons RA, Suponitsky-Kroyter I, Selak MA. Progressive accumulation of mitochondrial DNA mutations and decline in mitochondrial function lead to beta-cell failure. J Biol Chem. 2005;280:28785-91.

59. Olivieri F, Lorenzi M, Antonicelli R, Testa R et al. Leukocyte telomere shortening in elderly Type2DM patients with previous myocardial infarction. Atherosclerosis. 2009;206:588-93. 
60. Guo N, Parry EM, Li LS, Kembou F et al. Short telomeres compromise beta-cell signaling and survival. PloS one. 2011;6:e17858. 